Biocontrol Science, 1998, Vol. 3, No. 1, 47-49

Note

\title{
Bacterial Susceptibility to Butyl $p$-Hydroxybenzoate in the Presence of Polyoxyethylene Cetyl Ether
}

\author{
MASAHIRO FUKAHORI ${ }^{1}$, SAKAE AKATSU ${ }^{1}$, HIROSHI SATO ${ }^{1}$, \\ AND TOSHIHISA YOTSUYANAGI ${ }^{2}$ \\ 'Central Research Laboratories, Zeria Pharmaceutical Co., Ltd., 2512-1, Oshikiri, Konan-machi, \\ Osato-gun, Saitama 360-01, and ' Faculty of Pharmaceutical Sciences, \\ Nagoya City University, Tanabedori, Mizuho-ku, Nagoya 467, Japan
}

Received 26 June 1997/Accepted 16 October 1997

\begin{abstract}
The effects of polyoxyethylene cetyl ether on the antibacterial activity of butyl phydroxybenzoate (BP) were studied using five strains of bacteria. The antibacterial activity of $B P$ in an aqueous solution was inhibited by the non-ionic surfactant due to a decrease in unbound BP in an aqueous phase resulting from the incorporation of BP into surfactant micelles, whereas it was greater than that anticipated from unbound BP. Non-ionic surfactant was thus concluded to increase the susceptibility of bacteria against BP due to direct interactions with the cells.
\end{abstract}

Key words : Butyl hydroxybenzoate/Antibacterial activity reduction/Drug susceptibility/Polyoxyethylene cetyl ether.

Non-ionic surfactants inhibit to some extent the antimicrobial activity of parabens, which were added to aqueous-based pharmaceuticals to give protection against microbial contamination (Shimamoto et al., 1973 ; Yamaguchi et al., 1982). The possible mode of the inactivation of parabens by non-ionic surfactants is a decrease in free parabens in the aqueous phase resulting from interactions between parabens and surfactant micelles, followed by the reduction of paraben uptake into microorganisms, as described in previous papers (Fukahori et al., 1996a, 1998). In this paper, the effects of polyoxyethylene cetyl ether on the susceptibility of bacteria to butyl paraben were studied using five strains of bacteria with a difference in the gram staining property.

Butyl p-hydroxybenzoate (BP, Ueno Pharmaceutical Co., Tokyo) and polyoxyethylene cetyl ether (PCE, Nikko Chemicals Co., Tokyo) were of the grade prescribed by The Japanese Pharmacopoeia Thirteenth Edition and The Japanese Cosmetic Ingredients Second Edition, respectively. Escherichia coli

*Corresponding author. Tel : +81-485-36-3456, Fax : + 81-485-36-1092.
$\mathrm{NIHJ}$, Pseudomonas aeruginosa IFO3080, Klebsiella pneumoniae ATCC4352, Staphylococcus aureus IFO12732 and Micrococcus lysodeikticus NCTC2665 were incubated at $37^{\circ} \mathrm{C}$ for $18 \mathrm{~h}$ in soybean-casein digest agar. Bacterial cells scraped aseptically from the agar medium were suspended in sterilized distilled water and diluted to a prescribed cell concentration. Each cell suspension $(0.1 \mathrm{ml})$ was inoculated in a 4.9 $\mathrm{ml} \mathrm{BP}$ solution with $0,0.25,0.5$ or $1.0 \mathrm{mg} / \mathrm{ml}$ of PCE. The BP concentration in the solution was adjusted to a multiple of $7.24 \times 10^{-5} \mathrm{M}$ to $1.09 \times 10^{-3} \mathrm{M}$. The inoculation was repeated three times at each $\mathrm{BP}$ and PCE concentration. The cell numbers in each solution, determined by the plate count method using soybeancasein digest agar, were $5.1 \times 10^{5} \mathrm{cell} / \mathrm{s} / \mathrm{ml}$ of $E$. coli, $8.3 \times 10^{5} \mathrm{cells} / \mathrm{ml}$ of $P$. aeruginosa, $1.1 \times 10^{6} \mathrm{cells} / \mathrm{ml}$ of $K$. pneumoniae, $1.1 \times 10^{6}$ cells $/ \mathrm{ml}$ of $S$. aureus and $7.0 \times 10^{5} \mathrm{cells} / \mathrm{ml}$ of $M$. lysodeikticus. After being kept at $25^{\circ} \mathrm{C}$ for $1,2,4$ or $6 \mathrm{~d}$, the aqueous BP solution with the cells $(0.1 \mathrm{ml})$ was inoculated in ca. $5 \mathrm{ml}$ of soybean-casein digest broth with lecithin and polysorbate 80 , and this was repeated twice. The minimum bactericidal concentration of $\mathrm{BP}(\mathrm{MBC})$ against each strain was determined after no bacterial growth in the broth 
was evident following the inoculation at $37^{\circ} \mathrm{C}$ for $2 \mathrm{~d}$ ( $P$. aeruginosa, K. pneumoniae, E. coli and $S$. aureus) or $6 \mathrm{~d}$ (M. lysodeikticus).

Parabens in an aqueous solution with non-ionic surfactants are incorporated into the micelles by hydrophobic and hydrophilic interactions, and the paraben concentration of the unbound form in an aqueous phase accordingly decreases (Fukahori et al., 1996b). The BP concentration of the unbound form with PCE micelles in the aqueous solution, containing the negligible volume of the cells for the measurement of $\mathrm{MBC}, C_{\mathrm{t}}$, is determined according to equation (1) (Fukahori et al., 1996a):

$$
K_{\mathrm{s}}=\frac{\left(C_{\mathrm{t}}-C_{\mathrm{f}}\right) / S}{C_{\mathrm{f}}}
$$

where $K_{\mathrm{s}}$ is the apparent partition coefficient of BP between PCE micellar and aqueous phases (2.23, Fukahori et al., 1996a), $C_{t}$ is the total BP concentration and $S$ the PCE concentration in the solution ( $w /$ v).

Table 1 shows the MBC of $\mathrm{BP}$ against $E$. coli in the PCE solution and the $C_{f}$ at the MBC determined using $K_{s}$ according to equation (1). The addition of PCE caused an increase in the MBC, with the MBC being more than $10.9 \times 10^{-4} \mathrm{M}$ of BP at $1.0 \mathrm{mg} / \mathrm{ml}$ of PCE. Free parabens in the aqueous phase have been gen-

TABLE 1. MBCs of BP against $E$. coli and the unbound BP concentration in aqueous solution $\left(C_{1}\right)$ at $\mathrm{MBC}$ in the presence of various concentrations of PCE.

\begin{tabular}{ccc}
\hline $\begin{array}{c}\text { PCE concn } \\
(\mathrm{mg} / \mathrm{ml})\end{array}$ & $\begin{array}{c}\mathrm{MBC}^{a} \\
\left(\mathrm{M} \times 10^{4}\right)\end{array}$ & $\begin{array}{c}C_{\mathrm{t}}^{b} \\
\left(\mathrm{M} \times 10^{4}\right)\end{array}$ \\
\hline 0 & 6.52 & 6.52 \\
0.25 & 8.93 & 5.74 \\
0.50 & 10.6 & 5.02 \\
1.00 & $>10.9$ & - \\
\hline
\end{tabular}

${ }^{a}$ The MBC was determined using aqueous BP solutions with a multiple of $7.24 \times 10^{-5} \mathrm{M}$ to $1.09 \times 10^{-3} \mathrm{M}$, after inoculation of $E$. coli for $1 \mathrm{~d}$. Data are the mean of three measurements.

${ }^{\circ}$ The $C_{\text {f }}$ was determined using $K_{\mathrm{s}}$ of the BP-PCE system (2.23) according to equation (1).

TABLE 2. MBCs of $B P$ against various bacterial strains in the absence and presence of $0.5 \mathrm{mg} / \mathrm{ml}$ of PCE and unbound BP concentration in aqueous solution $\left(C_{t}\right)$ at the MBC in the presence of PCE.

\begin{tabular}{|c|c|c|c|c|}
\hline \multirow{3}{*}{ Bacterium } & \multirow{3}{*}{$\begin{array}{l}\text { Time after } \\
\text { inoculation } \\
\text { (d) }\end{array}$} & \multirow{2}{*}{\multicolumn{2}{|c|}{$\frac{\mathrm{MBC}\left(\mathrm{M} \times 10^{4}\right)^{a}}{\mathrm{PCE} \text { concn }(\mathrm{mg} / \mathrm{ml})}$}} & \multirow{3}{*}{$\begin{array}{c}C_{f}^{b} \\
\left(M \times 10^{4}\right)\end{array}$} \\
\hline & & & & \\
\hline & & 0 & 0.5 & \\
\hline \multirow[t]{4}{*}{$P$. aeruginosa } & 1 & $>10.9$ & $>10.9$ & $>5.13$ \\
\hline & 2 & $>10.9$ & $>10.9$ & $>5.13$ \\
\hline & 4 & 10.5 & $>10.9$ & $>5.13$ \\
\hline & 6 & 8.45 & $>10.9$ & $>5.13$ \\
\hline \multirow[t]{4}{*}{ E. coli } & 1 & 6.52 & 10.6 & 5.02 \\
\hline & 2 & 6.27 & 10.4 & 4.91 \\
\hline & 4 & 5.07 & 9.17 & 4.34 \\
\hline & 6 & 4.71 & 8.87 & 4.19 \\
\hline \multirow[t]{4}{*}{ K. pneumoniae } & 1 & 5.79 & 9.90 & 4.68 \\
\hline & 2 & 5.31 & 8.20 & 3.88 \\
\hline & 4 & 4.58 & 6.76 & 3.20 \\
\hline & 6 & 4.52 & 6.52 & 3.08 \\
\hline \multirow[t]{4}{*}{ S. aureus } & 1 & 10.1 & $>10.9$ & $>5.13$ \\
\hline & 2 & 7.96 & $>10.9$ & $>5.13$ \\
\hline & 4 & 6.28 & 9.41 & 4.45 \\
\hline & 6 & 4.59 & 7.00 & 3.31 \\
\hline \multirow[t]{4}{*}{ M. Iysodeikticus } & 1 & 6.76 & 7.61 & 3.60 \\
\hline & 2 & 5.31 & 6.52 & 3.08 \\
\hline & 4 & 3.62 & 6.28 & 2.97 \\
\hline & 6 & 3.62 & 4.10 & 1.94 \\
\hline
\end{tabular}

${ }^{a}$ The MBC was determined using aqueous BP solutions with a multiple of $7.24 \times 10^{-5} \mathrm{M}$ to $1.09 \times 10^{-3} \mathrm{M}$. Data are the mean of three measurements.

${ }^{b}$ Determined in the same manner as Table 1. 
erally regarded as their effective form in surfactant solutions (O'Neill et al., 1979; Patel and Romanowski, 1970; Shimamoto et al., 1973); but, the $C_{f}$ at the MBC in the presence of PCE was smaller than the MBC in the absence of PCE $\left(6.52 \times 10^{-4} \mathrm{M}\right)$ and decreased with an increase in PCE. Thus, the antibacterial activity of BP in a PCE solution was greater than that anticipated from $C_{f}$. This may be attributed to an increase in the susceptibility of bacteria against BP, possibly due to direct interactions between PCE and the cells.

Table 2 shows the MBC of $\mathrm{BP}$ against various strains in the absence and presence of $0.5 \mathrm{mg} / \mathrm{ml}$ of PCE and the $C_{f}$, determined in the same manner as Table 1. The MBC decreased with standing time after inoculation of bacteria in the $\mathrm{BP}$ solution and increased with added PCE. The characteristics of bacteria may cause differences in a decrease in the MBC by the standing time. Well defined minimum inhibitory concentration of parabens against gram-negative bacteria was generally greater than that against grampositive bacteria (Aalto et al., 1953 ; Shibasaki, 1969, 1974). Similarly, the present results are generally consistent with the above consideration even in the presence of surfactants. Hydrophobicity of the cell surface is greater for gram-positive bacteria than gram-negative bacteria (Kourai et al., 1989). High susceptibility of hydrophobic gram-positive bacteria to parabens thus suggests that hydrophobic interactions between BP and hydrophobic constituents in bacterial cells considerably contribute to the antibacterial action. The $C_{f}$ of $\mathrm{BP}$ at the MBC in the presence of PCE was smaller than the MBC in the absence of PCE, except for $P$. aeruginosa with unknown MBC. PCE may be inactive against various strains at experimental concentrations in analogy with its inactivity to $E$. coli (Fukahori et al., 1996c). In conclusion, PCE enhanced the susceptibility of bacteria against BP presumably due to direct interactions between the surfactant and bacterial cells, regardless of the difference in the gram staining property.

\section{REFERENCES}

Aalto, T. R., Firman, M. C., and Rigler, N. E. (1953) pHydroxybenzoic acid esters as preservatives I. J. Am. Pharm. Assoc. Sci. Ed., 42, 449-457.

Fukahori, M., Takatsuji, Y., Takahashi, H., Sato, H., and Yotsuyanagi, T. (1996a) Estimation of distribution of $p$-hydroxybenzoic acid esters between nonionic surfactant micellar and aqueous phases. Chem. Pharm. Bull., 44, 1068-1073.

Fukahori, M., Takatsuji, Y., Seki, M., Takahashi, H., Sato, H., and Yotsuyanagi, T. (1996b) Interaction between hydroxybenzoic acid esters and polyoxyethylene cetyl ether. Chem. Pharm. Bull., 44, 577581.

Fukahori, M., Akatsu, S., Sato, H., and Yotsuyanagi, T. (1996c) Effects of structures of polyoxyethylene alkyl ethers on uptake of butyl $p$-hydroxybenzoate by Escherichia coli and antibacterial activity. Chem. Pharm. Bull., 44, 2335-2337.

Fukahori, M., Takatsuji, Y., Akatsu, S., Sato, H., and Yotsuyanagi, T. (1998) Effects of polyoxyethylene cetyl ether on the cellular uptake and antibacterial activity of butyl p-hydroxybenzoate against Escherichia coli. Biocontrol Sci., 3, 23-29.

Kourai, H., Takeuchi, H., Muramatsu, K., and Shibasaki, I. (1989) Relationship between hydrophobicity of bacterial cell surface and drugsusceptibility to alkylpyridinium iodides. BokinBobai, 17, 119-128.

O'Neill, J. J., Peelor, P., Peterson, A., and Strube, C. (1979) Selection of parabens as preservatives for cosmetics and toiletries. J. Soc. Cosmet. Chem., 30, 25-38.

Patel, N. K., and Romanowski, J. M. (1970) Influence of partitioning and molecular interactions on in vitro biologic activity of preservatives in emulsions. J. Pharm. Sci., 59, 372-376.

Shibasaki, I. (1969) Antimicrobial activity of alkyl esters of $p$-hydroxybenzoic acid. J. Ferment. Technol., 47, 167-177.

Shibasaki, I. (1974) Antimicrobial characteristics of some alkyl esters of $p$-hydroxybenzoic acid (in Japanese). Bokin-Bobai, 2, 3-8.

Shimamoto, T., Ogawa, Y., and Ohkura, N. (1973) Ultrafiltration method for measuring free preservatives in aqueous phase of oil-in-water emulsions. Chem. Pharm. Bull., 21, 316-322.

Yamaguchi, M., Asaka, Y., Tanaka, M., Mitsui, T., and Ohta, S. (1982) Antimicrobial activity of butylparaben in relation to its solubilization behavior by nonionic surfactants. J. Soc. Cosmet. Chem., 33, $297-$ 307. 